\title{
A Financial Analysis Approach on the Impact of Economic Interdependence on Interstate Conflicts
}

\author{
Victoria Pistikou ${ }^{1}$, Eftychia Tsanana $^{2}$, Thomas Poufinas ${ }^{1 *}$ (i) \\ ${ }^{1}$ Department of Economics, Democritus University of Thrace, Komotini, Greece \\ ${ }^{2}$ University of Macedonia, Thessaloniki, Greece \\ Email: *tpoufina@econ.duth.gr
}

How to cite this paper: Pistikou, V., Tsanana, E., \& Poufinas, T. (2021). A Financial Analysis Approach on the Impact of Economic Interdependence on Interstate Conflicts. Theoretical Economics Letters, 11, 947-961.

https://doi.org/10.4236/tel.2021.115060

Received: August 17, 2021

Accepted: October 8, 2021

Published: October 11, 2021

Copyright $\odot 2021$ by author(s) and Scientific Research Publishing Inc. This work is licensed under the Creative Commons Attribution International License (CC BY 4.0).

http://creativecommons.org/licenses/by/4.0/

\begin{abstract}
There is a long-standing debate on whether economic interdependence can have an impact and play a crucial role in diminishing interstate conflict. Two schools of thought advocating two opposite beliefs regarding this debate are Realism and Liberalism. The former suggests that economic interdependence does not necessarily promote peace, whereas the latter trusts that it does. According to Liberalism, there is a direct connection between trade and conflict, in other words, between economic factors and security issues. On the contrary, Realists argue that what applies to the international system also applies to trade policy; hence economic cooperation among states has a limited effect when it comes to national security issues. This study attempts to shed light on this debate, i.e. whether bilateral economic relations can affect interstate conflict. To achieve that it uses a theoretical framework derived from the disciplines of international political economy enhanced with a quantitative-financial analysis that employs a series of econometric models in order to identify macroeconomic variables that have an impact on the interstate conflict. Three dyads of countries that have recorded interstate conflict are employed (India-Pakistan, Russia-Ukraine and Yemen-Saudi Arabia). The defense expenses are used as a proxy of interstate conflict, whereas the imports and the exports from one country to the other are the variables that capture the economic interdependence. Evidence is found that exports have a positive impact on defense expenses. This means that economic interdependence does not necessarily lessen interstate conflict, which can be useful at the hands of policymakers.
\end{abstract}

\section{Keywords}

Bilateral Trade, Defense Expenses, Dyads, Economic Interdependence, 
Financial Analysis, Interstate Conflict

\section{Background Discussion and Literature Review}

Does economic interdependence affect conflicts? The aim of this research is to examine the impact of bilateral economic relations on interstate conflicts. International Political Economy, as a subfield of International Relations, examines the relationship between economics and politics in world affairs. More precisely, it examines the causes which affect the world-economy. On the one hand, markets do not operate completely by themselves, since all products are not traded and exchanged in the same terms and are obliged to get into line with rules, norms, etc. On the other hand, state leaders cannot rule the global economy or financial institutions; they however affect them according to the structure of their state's domestic economy. Thus, both state and non-state actors interact in a global context shaping the economic and political landscape, creating ties of economic interdependence.

In this context, there is a long-standing debate on whether economic interdependence promotes peaceful relations between states or not. There are arguments in both directions represented primarily by two schools of thoughts: Realism and Liberalism. The theoretical background that depicts the principles of the two schools is presented below.

Realism interprets the political and economic behavior of states. Cooperation between states creates asymmetric gains for each partner, therefore states care about relative gains (Grieco, 1988). In addition, those who agree with the argument that today's economic interdependence has changed the environment and the nature of international politics, should be more skeptical, since groups and states have managed to increase their gains through economic growth and international cooperation. When the levels of economic interdependence start rising, states become more suspicious regarding the loss of their autonomy and the costs involved, as the result of interdependence. This is due to the fact that societies care more for their gains and they are not willing to sacrifice their welfare in favor of interdependence. The raising levels of economic interdependence make states more anxious about preserving their autonomy, their access to foreign markets and valuable raw materials as well as the cost that economic interdependence entails (Gilpin, 1981). Last but not least, according to Realism, economic policies are supportive of security issues, since economy is a tool of foreign policy. As Mastanduno (1998) mentions, the state's strategic principles are primarily based on three variables. The first is the structure of the International System, the second is the role of policy-makers and the third is the state's position in international economic competition.

Liberalism introduced "Idealism" (Dunne, 2008) as a new perspective for understanding international politics. For Liberals, determinants such as individual 
liberty, interdependence, prosperity, democratic values, free trade, collective security as well as the power of public opinion are what promote peaceful relations among states. Although they agree with Realists that the international system is dominated by anarchy, that is to say by the absence of a power above all which would be able to control repressive mechanisms and maintain world order and peace, Liberals are more optimistic regarding peaceful cooperation among states. They argue that war can be avoided since there are other factors which increase people's prosperity and cooperation, such as domestic and international institutions and high levels of democratic values. In addition, Neo-Liberals also built on Cobden's beliefs about the peaceful impact of free trade on states and on Keohane's and Nye's (2013) argument about interaction in several sectors. According to the latter, interests groups, transnational corporations and other actors should be taken into account because these non-state actors not only influence decision-making but also make states more interdependent, by raising the levels of collaboration as well as the costs of a potential withdrawal from these common fields. For example, the Bretton Woods system or NATO represents the institutionalized power of the USA. Also, Keohane's and Nye's (2001) complex interdependence does not agree with Realists' distinction between high and low politics. On the contrary, they mention that there are many interactions among non-state actors which define international politics, and therefore military force is no more efficient as a tool of statecraft.

Moving from the theoretical background to the available bibliography, we realize that there is ample literature that explores the relation of economic interdependence and interstate conflict. Most of the authors argue that not only does trade promote peace, but also that conflict decreases trade (Long, 2008). According to the Liberal Interdependence approach, the division of labor in the international economy is the main determinant, creating high levels of interdependence between states thereby preventing them from engaging in militarized conflict and war. The Liberals are based on Keohane's and Nye's (1977) complex interdependence approach, on the role of International Institutions as well as on Democratic Peace.

On the other hand, regarding the theoretical aspect of Realism, according to Grieco (1988) states do not focus only on absolute gains, as liberals argue, but they also care about relative gains. As Grieco mentions, "For realist theory, state efforts to cooperate entails these dangers plus the much greater risk, for some states, that cooperation might someday result in lost independence or security" (Grieco, 1988: p. 502). In addition, according to Gilpin (1981), those who agree with the argument that today's economic interdependence has changed the environment and the nature of international politics, should be more skeptical, since groups and states have managed to increase their gains through economic growth and international cooperation. More specifically, Hirschman's (1945) hypothesis that a stable economic growth and a global economic market would diminish the struggle for power between states through cooperation and profita- 
bility did not confirm, since economic interdependence and mutual gains has not yet diminished state's efforts for promoting their national interests against the others.

In addition, Krasner (1979) by examining the US foreign Policy towards American investment in raw materials divides the state and the national interest from society. He argues that a state is an autonomous entity which promotes the national interest; therefore the state's behavior cannot be explained by class interests. Therefore, society's interests are not always identified with the national interests. Mastanduno's (1998) argument in "Economics and Security" is that economic policies are supportive of security issues and that they are primarily based on three variables. The first is the structure of the International System, the second is the role of policy-makers and the third is the state's position in international economic competition. Therefore, economy is a tool of foreign policy which should be used according to state's strategic principles. According to the Realists, such as Gowa and Mansfield (1993), what applies to the international system also applies to trade policy. That is to say that there is a security risk, which derives from the anarchy in the international system, which makes states act as rational players. However, Oneal and Russett (1999) argued that trade is a sufficient factor which is able to reduce conflict between dyads and conclude that trade has major benefits for contiguous dyads but little effect on irrelevant dyads and interdependence decreases the likelihood of militarized disputes between major powers.

Morrow (1999), examined how trade affects conflicts through a game-theoretic approach, focusing on the reasons for which an interstate conflict occurs and escalates. It is his view that the common argument is that international trade affects conflict and, more specifically, prevents states from taking military actions because of the high costs which are going to be faced in the event of a reduction in their commercial relations. However, according to game-theoretic models, there are unobservable factors which make trade effectiveness seem vague because both of the rival states try to interpret the opponent's resolve. Therefore, his argument is that the escalation of the conflict depends on what one side believes about the relative resolve of the other and the correlation between trade and conflict is the result of anticipation by economic actors, since trade flows reflect relations between two countries in a wider sense.

Gartzke et al. (2001) examined how economic interdependence contributes to peace. Their main argument is that economic costs and benefits are not enough to deter militarized conflict between states unless capital interdependence is high. Hegre (2004) also argued that in symmetric dyads, trade reduces conflict. Therefore, "trade efficiency" is more likely to happen in terms of symmetric dyads than asymmetric.

According to many researchers, like Li and Sacko (2002), trade between two rival states tends to decrease either because of territorial disputes or other conflictual actions. On the other side, states with cooperation on mutual gains and 
interests trade more than others and consequently, "trade follows the flag". Long and Leeds (2006) examined the commercial activity of states within military alliances with or without economic provisions. As many scholars have shown, trade among allies is at higher level than trade among non-allies. The authors' main argument is that there is a connection between security and trade agreements; this helps the states overcome their problems and raise the level of co-operation between them. More specifically, they argue that when in an alliance there are military provisions coupled with economic provisions, the states are likely to trade more with each other than compared with states that are in a strictly military alliance.

Gelpi and Grieco (2008) on the other hand, by examining different data through a time series analysis between democratic and autocratic states between 1950 and 1992, argued that since trade promotes economic growth, there is a high political cost for democratic leaders to initiate a military conflict with trading partners. However, this does not apply for the autocratic states. Therefore, trade dependence in general "is not a constraint on the conflict behavior of autocratic leaders"; hence trade by itself cannot prevent military conflict.

Maoz (2009) developed a Social Network Analytic Approach in order to measure economic interdependence across levels of analysis, by measuring the cost of breaking economic ties. He argued that the Liberal paradigm is confirmed regarding the effects of strategic and economic interdependence on conflict.

Herge et al. (2010) focused on the interaction between the effects of conflict and trade, giving a new approach which enriches the Liberals' theory and shows that trade promotes peace. Their main argument is that trade promotes peace but at the same time it is reduced because of conflict and this can be shown if the gravity model can be taken into consideration in conflict analysis. They also base their argument on economic interdependence, mentioning that conflict and violence in general has a significant effect on commercial relations and this, in cost and benefits terms, makes trade disruption unprofitable and consequently peace is promoted.

Li and Reuveny (2011) argued that their theoretic model predicts the impact of bilateral trade on conflict and a combination of imports and exports in specific sectors of commercial relations such as agriculture and fisheries, energy, chemicals and minerals goods, can determine the state's intention concerning conflict.

Goldsmith (2013) argued that trade interdependence mainly affects the onset of the conflict by inhibiting militarized disputes and has no relationship with conflict escalation and therefore trade volume reduces the likelihood of a more violent conflict. In addition, Seitz et al. (2015) argued that lower trade cost will cause lower defense expenditure with domino effect on other countries and this will lead to more peaceful relations. However, in a study regarding the sino-japanese conflict (Poufinas and Pistikou, 2017) it is seen that increasing im- 
ports did not cause a reduction in military spending. In addition, Chang and Sellak (2021) examine trade's impact on peaceful relationships through Free Trade Agreements. They conclude that free trade agreements, even through third parties and not necessarily between rivals, may have pacifying or appeasing effect on military conflicts.

Up to now, the independent variables of low politics, that is all sectors apart from defense and foreign policy issues, defined the analytical framework under which Liberals supported their arguments, and they examined their hypotheses through econometric models and statistical analysis. More specifically, alliances, trade flows, Gross Domestic Product, contiguity as well as political regime have been the most common variables, among others, used by the Liberals as observable factors. Some other authors differentiated their approach by taking into consideration variables such as trade expectations (Copeland, 1996), common interests (Li and Sacko, 2002), interaction between domestic politics and the international system (Kapstein, 2003), income ratio (Martin et al., 2008), as well as Preferential Trade Agreements (Herge et al., 2010; Long, 2008). There are also some differences regarding the dependent variable since some of the Liberals have considered trade to be the dependent variable (Barbieri and Levy, 1999; Long and Leeds, 2006) compared to others (Copeland, 1996; Oneal and Russett, 1999; Gartzke et al., 2001; Powers, 2004; Martin et al., 2008; Li and Reuveny, 2011), who considered Militarized Interstate Disputes (MIDs) as the dependent variable. However, it is difficult to categorize the studies that find negative or positive correlation between economic interdependence and interstate conflict because this issue is examined under many and different circumstances, as analyzed above.

Nevertheless, they do not consider the state as a determinant (Poufinas and Pistikou, 2018), emphasizing only on economic factors which act independently. This is an important omission, since they are examining interstate conflicts. For example, Morrow (1999) examines trade flows, contiguity, military capabilities and political regime without taking into consideration the state's position in the international system and the national interest. For example, Long and Leeds (2006) argue that the linkage of Economic and Security issues can raise trade levels, but they do not refer to the impact of this linkage on the state's dynamics and its ability to promote its influence.

The present study investigates with the use of financial-econometric analysis whether bilateral trade (measured by imports and exports) can impact interstate conflict (captured by defense expenses). As it employs quantitative tools it provides a fresh approach in a long-standing question. Its novelty is that it attempts to explore whether there is a link between interstate conflict, expressed by defense expenses, and bilateral trade, expressed by imports and exports. All other terms being equal, the anticipation is that if the bilateral trade increases then the defense expenditure will decrease-according to Liberalism. However, Realism does not subscribe to this point of view. To the best of the knowledge of the au- 
thors this approach has not been exploited so far, i.e. the examination of the correlation between defense expenditure and bilateral trade apart possibly from Seitz et al. (2015), who explored a similar direction and found a positive correlation between trade cost and defense expenditure, as explained above.

\section{Data and Variables}

Our data set consists of time series for the defense expenses (dependent variable), as well as bilateral trade-captured by imports and exports (independent variables) between the two rivals. The dataset covers 3 dyads of countries that are in a permanent/continuing conflict: India-Pakistan, Russia-Ukraine and Yemen-Saudi Arabia. These 3 dyads of countries have in common their number of casualties.

The data are derived from The World Bank (2017) and the OECD (2017), as well as UN Comtrade (2018) and UNCTAD (2018) covering the years from 1980 to 2017.

Defense expenses increase (decrease) when interstate conflict increases (decreases) and this is the reason they have been chosen as its proxy. Imports and exports from one country to the other depict the bilateral trade that takes place between the two countries, which reveals potential economic interdependence, and as such they have been selected as its proxies. These variables were selected based on data availability since eighteen observations created balanced datasets.

\section{Methods}

When analyzing time series, it is crucial, before performing any technique to test the possible existence of a unit root. These tests, named as unit root tests, are capable of capturing possible time dependence of the time series. For instance, a stochastic sequence $\left\{y_{t}\right\}$ is weakly stationary if for all $t$ and $t$ - $s$ the following conditions coincide (for $E$ the expected value):

$$
\begin{gathered}
E\left(y_{t}\right)=E\left(y_{s}\right)=\mu, \\
E\left(y_{t}-\mu\right)^{2}=E\left(y_{t-s}-m\right)^{2}=\sigma^{2}, \\
E\left(y_{t}-\mu\right)\left(y_{t-s}-\mu\right)=E\left(y_{t-j}-\mu\right)\left(y_{t-j-s}-\mu\right)=\gamma_{s} .
\end{gathered}
$$

That is, the mean, variance and covariance are invariant to time.

Suppose that there is a series $\left\{y_{t}\right\}$ expressed in an autoregressive (AR) process of order one, AR (1):

$$
y_{t}=a y_{t-1}+\varepsilon_{t},
$$

where $\alpha<1$ and $\varepsilon_{t}$ is white noise. We can estimate the parameters in Equation (4) with the use of ordinary least squares (OLS); the estimator is efficient and the series is stationary since $\alpha<1$. The hypothesis testing of these tests relies upon the following pair of hypotheses:

$\mathrm{H}_{0}: \alpha=1$, existence of a unit root

$\mathrm{H}_{1}: \alpha<1$, stationarity 
This is a legitimate test since the null is a refutable hypothesis, even though the power against a local alternate is negligible. Equation (4) is transformed and being used in the relevant tests, as follows:

$$
\Delta y_{t}=\gamma y_{t-1}+\varepsilon_{t},
$$

where $\gamma=0$ implies $\alpha=1$, which implies a unit root in $\left\{y_{t}\right\}$. In this equation, it is possible to allow a drift by including an intercept:

$$
\Delta y_{t}=a_{0}+\gamma y_{t-1}+\varepsilon_{t} \text {. }
$$

A linear trend may be also allowed:

$$
\Delta y_{t}=a_{0}+\gamma y_{t-1}+a_{2} t+\varepsilon_{t} .
$$

In any case, the pair of tested hypotheses is transformed to

$\mathrm{H}_{0}: \gamma=0$, existence of a unit root

$\mathrm{H}_{1}: \gamma<0$, stationarity

If the $p$-value is lower than the significance level, then the null hypothesis is rejected, that is the examined time series is stationary. On the other hand, if the p-value is larger than the significance level, then the $\mathrm{H}_{0}$ hypothesis is accepted, that is the examined time series has a unit root.

After examining for the existence of a unit root in the time series, the analysis proceeds with a pooled OLS estimation-employed in cases of sample size problems. By using independently pooled cross sections the sample size can be increased and pooled cross-sections have minor statistical complications. In the context of this methodology, the intercept across time periods differs in order to capture the case that some distributions may differ. The analysis is enriched with the fixed-effects approach so as to capture the impact of variables that vary over time and explore the relationship between predictor and outcome variables within a country that has its own individual characteristics. This method also excludes the impact of all time-invariant characteristics in order to have the net effect of estimators upon the dependent variable.

Consider the panel regression model

$$
y_{i t}=\beta_{0}+\beta_{1} X_{i t}+z_{1} K_{i t}+\varepsilon_{i t},
$$

where $K_{i t}$ includes time-invariant heterogeneities across cross units i. If the effect on $y_{i t}$ is expressed by the variable $X_{i p}$ keeping the exogenous variable $K_{i t}$ constant, then

$$
\delta_{i t}=\beta_{0}+z_{1} K_{i t}+\varepsilon_{i t} .
$$

This means that the variation of parameters $\delta_{i t}$ is due to $K_{i t}$ These $\delta_{i t}$ parameters capture individual specific intercepts of every cross unit and this is called fixed-effect of cross unit $i$.

The fixed effects model could be generalized in order to include more independent variables that may explain the variation of the dependent variable. Equation (8) could be generalized as follows:

$$
y_{i t}=\beta_{0}+\beta_{1} X_{1 t}+\cdots+\beta_{k} X_{i t}+z_{1} K_{i t}+\varepsilon_{i t},
$$


where $K_{i t}$ includes time-invariant heterogeneities across cross units $i$, and $X_{1 t}, \cdots, X_{i t}$ are possible determinants of $y_{i t}$ (Wooldridge, 2016).

The limited samples limit significantly the case of using time series analysis by dyad due to the fact that the models face reliability issues. Consequently, panel data analysis was selected in order to combine both the cross-sectional and time series dimensions. Initially adequate tests were performed so as to decide over the integration properties of the series. After verifying the degree of integration of the relevant series pooled OLS was employed along with fixed effects estimation in these 3 dyads of countries to measure economic interdependence between the rivals and measure its impact on the conflict.

The variables introduced in the models, along with the rationale of their choice are depicted in Table 1.

\section{Empirical Results}

Initially, unit root tests were performed in order to decide over the integration of the selected series. According to these tests, the series was found to be non-stationary at levels and became stationary at first differences. Then the relevant variables in first differences and logarithms were used.

The results of the pooled OLS and the fixed effects estimation methods are presented in Table 2 and Table 3 that follow. Table 2 depicts two different regressions estimated with two different methods. Models (1) and (2) both have as dependent variable the defense expenses of country 1 . In the case of Model (1), only exports from country 1 to country 2 have significant impact on defense expenses, meaning that as exports increase, defense expenses increase as well, ceteris paribus in both models. More specifically, exports from countries set as 1 are statistically significant at the $10 \%$ significance level. Based on the OLS estimator, it seems that these exports affect positively defense expenses, meaning that if exports increase by $1 \%$ then defense expenses increase by $13.3 \%$. As for the fixed estimator, its value is quite close to the OLS one. The effect upon the defense expenses, ceteris paribus, is interpreted by noticing that a $1 \%$ increase in exports results in a $14.4 \%$ increase in the defense expenses. In these two models, the constant term is also statistically significant at the $5 \%$ significance level and

Table 1. Dependent and independent variables per model and selection rationale.

\begin{tabular}{|c|c|c|c|c|c|}
\hline \multirow{3}{*}{$\begin{array}{l}\text { Model - } \\
\text { (1) }\end{array}$} & \multicolumn{5}{|c|}{ Variables } \\
\hline & \multirow{2}{*}{$\begin{array}{c}\text { Dependent } \\
\text { Defense expenses-country } 1\end{array}$} & \multirow{3}{*}{$\begin{array}{l}\text { Rationale } \\
\text { The choice of defense } \\
\text { expenses as a proxy of } \\
\text { interstate conflict is justified } \\
\text { by the fact that they reflect }\end{array}$} & \multicolumn{2}{|c|}{ Independent } & \multirow{2}{*}{$\begin{array}{l}\text { Rationale } \\
\text { The selection of exports and } \\
\text { imports as proxies of economic }\end{array}$} \\
\hline & & & Exports_1 to 2 & Exports_2 to 1 & \\
\hline (2) & Defense expenses-country 1 & & Imports_1 to 2 & Imports_2 to 1 & $\begin{array}{l}\text { interdependence is explained } \\
\text { by the fact that they reflect the }\end{array}$ \\
\hline (3) & Defense expenses-country 2 & the understanding of the & Exports_1 to 2 & Exports_2 to 1 & magnitude of the bilateral trade \\
\hline (4) & Defense expenses-country 2 & $\begin{array}{l}\text { country with regards to the } \\
\text { threat posed by the rival. }\end{array}$ & Imports_1 to 2 & Imports_2 to 1 & $\begin{array}{l}\text { that takes place between } \\
\text { the countries. }\end{array}$ \\
\hline
\end{tabular}

Source: Created by the authors for elaboration purposes. 
Table 2. The impact of exports and imports to the defense expenses of country 1 .

\begin{tabular}{ccccc}
\hline Method & OLS & FE & OLS & FE \\
\hline $\begin{array}{c}\text { Dependent Variable } \\
\text { Defense expenses_country 1 }\end{array}$ & \multicolumn{2}{c}{ (1) } & & \\
Independent Variables & & & & \\
Exports_1 to 2 & $0.133^{*}$ & $0.144^{*}$ & & \\
Exports_2 to 1 & 0.061 & 0.066 & & 0.175 \\
Imports_1 to 2 & & & 0.176 & 0.029 \\
Imports_2 to 1 & & & 0.015 & $0.085^{* *}$ \\
Constant term & $0.080^{* *}$ & $0.079^{* *}$ & $0.086^{* *}$ & \\
F-stat & 8.772 & & 5.174 & \\
J-stat & & 8.491 & & 0.64 \\
$p$-value & 0.102 & 0.105 & 0.162 & 0.177 \\
\hline
\end{tabular}

Note: ${ }^{*}$ significance at the $5 \%$ level, and ${ }^{*}$ significance at the $10 \%$ level. Country 1 : India, Russia and Yemen. Source: Author estimates with data from The World Bank (2017), the OECD (2017), UN Comtrade (2018) and UNCTAD (2018).

Table 3. The impact of exports and imports to the defense expenses of country 2.

\begin{tabular}{ccccc}
\hline Method & OLS & FE & OLS & FE \\
\hline $\begin{array}{c}\text { Dependent Variable } \\
\text { Defense expenses_country 2 }\end{array}$ & \multicolumn{2}{c}{ (3) } & & \\
Independent Variables & & & & \\
Exports_1 to 2 & $0.121^{*}$ & $0.125^{* *}$ & & \\
Exports_2 to 1 & 0.007 & 0.077 & & \\
Imports_1 to 2 & & & 0.093 & 0.095 \\
Imports_2 to 1 & & & 0.110 & 0.112 \\
Constant term & $0.064^{* *}$ & $0.064^{* * *}$ & $0.061^{* *}$ & $0.061^{* *}$ \\
F-stat & 121.21 & & 1.886 & \\
J-stat & & 74.580 & & 1.939 \\
$p$-value & 0.001 & 0.013 & 0.162 & 0.340 \\
\hline
\end{tabular}

Note: ${ }^{* *}$ significance at $1 \%$ the level, ${ }^{* *}$ significance at the $5 \%$ level, and ${ }^{*}$ significance at the $10 \%$ level. Country 2: Pakistan, Ukraine and Saudi Arabia. Source: Author estimates with data from The World Bank (2017), the OECD (2017), UN Comtrade (2018) and UNCTAD (2018).

its estimations with both methods is almost the same ( 0.080 and 0.079 respectively). This means that when all variables are equal to 0 , defense expenses equal to 1.08 million USD almost at their minimum level. Moreover, Model (2) has the same dependent variable as Model (1), though includes imports between two countries as independent variables. According to the respective results, the current sample indicates no effect upon defense expenses by imports since both independent variables are statistically insignificant in both methods. In these 
models, the constant term is statistically significant at the $5 \%$ significance level and its estimations are almost the same. It seems that when the other variables equal to 0 , defense expenses increase by approximately $8.5 \%$.

The analysis is replicated having though in all models the defense expenses of country 2 as the dependent variable. The results are reported in Table 3. Table 3 depicts two different regressions estimated with two different methods, OLS and FE. Models (3) and (4) both have as dependent variable the defense expenses of country 2. In the case of Model (3), only exports coming from country 1 to country 2 have significant impact on defense expenses, meaning that as exports increase, defense expenses increase, ceteris paribus in both models. More specifically, there is a statistically significant relation in both models at the $10 \%$ and $5 \%$ levels respectively. Based on the OLS estimator, it seems that exports of country 1 affect also positively the defense expenses of country 2 , meaning that a $1 \%$ increase of exports results in a $12.1 \%$ increase of defense expenses in country 2. As far as the fixed effect estimator is concerned, the effect is almost the same. The effect upon the defense expenses of country 2, ceteris paribus, is interpreted by noticing that an increase by $1 \%$ results in a $12.5 \%$ increase in the defense expenses of country 2. In these two models, the constant term is also statistically significant at the $5 \%$ significance level and its estimations in both methods are almost the same ( 0.080 and 0.079 respectively). This means that when all variables are equal to 0 , the defense expenses of country 2 equal 1.08 million USD almost at their minimum level as reported also in Models (1) and (2). Moreover, Model (4) has the same dependent variable as Model (3) though different variables are included. Model (4) includes imports between two countries as independent variables. According to the respective results, the current sample indicates no effect upon defense expenses of country 2 by imports since both independent variables are statistically insignificant in both methods. In these models, the constant term is statistically significant at the $5 \%$ significance level and its estimation is almost the same as in Model (3). It seems that when all the other variables are equal to 0 , defense expenses of country 2 have a minimum level of approximately 1.08 million USD on average.

In the context of this analysis, several regressions were run. All the above models of two independent variables were also estimated in the context of simple regressions. However, only the reported results indicated statistical significance for the current sample.

\section{Interpretation and Implications}

The results of the econometric models indicate that the exports from country 1 to country 2 have a positive and statistically significant impact on the defense expenses of both countries. Imports on the other hand have no statistical significance.

This indicates that the increase of economic interdependence does not lead to a decrease of the interstate conflict as captured by defense expenses. On the 
Table 4. Result summary and explanation.

\begin{tabular}{|c|c|c|c|c|c|c|}
\hline \multirow{2}{*}{ Model } & \multirow{2}{*}{ Dependent Variables } & \multicolumn{5}{|c|}{ Independent Variables Sign and Significance } \\
\hline & & Exports_1 to 2 & Exports_2 to 1 & Imports_1 to 2 & Imports_2 to 1 & Explanation \\
\hline (1) & $\begin{array}{c}\text { Defense } \\
\text { expenses-country } 1\end{array}$ & $+^{*}$ & + & & & $\begin{array}{l}\text { Only exports from country } 1 \\
\text { to country } 2 \text { have a positive }\end{array}$ \\
\hline (2) & $\begin{array}{c}\text { Defense } \\
\text { expenses-country } 1\end{array}$ & & & + & + & $\begin{array}{l}\text { and statistically significant } \\
\text { impact to the defense } \\
\text { expenses of country } 1 \text { and }\end{array}$ \\
\hline (3) & $\begin{array}{c}\text { Defense } \\
\text { expenses-country } 2\end{array}$ & $+^{*}$ & + & & & $\begin{array}{l}\text { country } 2 \text {. All other } \\
\text { variables have a positive }\end{array}$ \\
\hline (4) & $\begin{array}{c}\text { Defense } \\
\text { expenses-country } 2\end{array}$ & & & + & + & $\begin{array}{l}\text { but statistically } \\
\text { insignificant effect. }\end{array}$ \\
\hline
\end{tabular}

Source: Created by the authors for elaboration purposes; ${ }^{*}$ significance at the $10 \%$ level.

contrary the increase of exports of country 1 to country 2 leads to an increase of the expenses of both countries. Hence, both countries seem to consider the conflict as vivid even though some trade activity is built. This may be attributed to the fact that the defense expenses of these countries are not necessarily related to the particular interstate conflict with the investigated pair in the dyad. It could also be due to the fact that the economic crisis has potentially led to a decrease of both the economic activity and the defense expenses in some cases. This explains partially the results. Furthermore, country 1 is not always the stronger economy. In addition, it is not necessarily the country that has initiated the conflict. These findings indicate that the topic needs to be further investigated so as to incorporate more dyads and potentially additional proxies of interstate conflict and economic interdependence in order to realize whether the latter impacts the former.

The impact of the independent variables and their explanation is summarized in Table 4.

In political terms, policymakers may find these empirical results interesting as they show that they cannot rely solely on the strengthening of bilateral trade in order to end or reduce the conflict. In addition, according to other studies, establishing a free trade area may be the way for fostering economic ties and interdependence with potential rivals, however, it will be difficult to have a critical impact on conflict if this cannot happen in bilateral level without any degree of economic integration. Therefore, we cannot expect, at least for the mentioned cases, de-escalation or elimination of the conflict caused by increased economic activity between the rivals. Therefore, other routes need to be explored so that an interstate conflict can be reduced or eliminated through trade.

\section{Conclusions and Further Research}

In the present analysis, a study of the impact of economic interdependence on interstate conflict was attempted with the use of a sample that consisted of three dyads of countries facing a similar context of interstate conflict: India-Pakistan, 
Russia-Ukraine and Yemen-Saudi Arabia. The results show that only exports from country 1 to country 2 have an impact on the level of defense expenses either for country 1 or for country 2 . This indicates that economic interdependence does not necessarily reduce interstate conflicts, since both countries 1 and 2 increase the defense expenses even though exports from country 1 to country 2 increase. Our contribution in the current literature relies upon the correlation between defense expenses and bilateral trade and is in the direction of the research of Seitz et al. (2015). There has been a big diversity of dependent variables employed in the relevant studies, such as trade expectations (Copeland, 1996), common interests ( $\mathrm{Li}$ and Sacko, 2002), interaction between domestic politics and the international system (Kapstein, 2003), income ratio (Martin et al., 2008), Preferential Trade Agreements (Herge et al., 2010; Long, 2008), trade (Barbieri and Levy, 1999; Long and Leeds, 2006), Militarized Interstate Disputes (MIDs) (Copeland, 1996; Oneal and Russett, 1999; Gartzke et al., 2001; Powers, 2004; Martin et al., 2008; Li and Reuveny, 2011). As all studies, it has certain limitations that primarily stem from data availability; three dyads where analyzed and certain proxies were used. Consequently the results depend purely on the span of the dataset. Our future research venues include the extension to additional dyads to more variables that are relevant to the interstate conflict as well as the economic interdependence, provided data become available. Furthermore, as indicated by the anonymous reviewers, it is worth investigating whether the strength of defense can affect the mutual trade of two countries. In addition, as recommended by the anonymous reviewers it would be interesting to apply game theoretical approaches in order to establish the hypotheses around economic interdependencies prior to the investigation of the correlation of the latter to the interstate conflict.

\section{Conflicts of Interest}

The authors declare no conflicts of interest regarding the publication of this paper.

\section{References}

Barbieri, K., \& Levy, J. (1999). Sleeping with the Enemy: The Impact of War on Trade. Journal of Peace Research, 36, 463-479. https://doi.org/10.1177/0022343399036004005

Chang, Y. M., \& Sellak, M. (2021). Endogenous Security, Third-Party Trade, and Interstate Disputes: A Conflict-Theoretic Analysis. Defense and Peace Economics. https://doi.org/10.1080/10242694.2021.1949830

Copeland, D. (1996). Economic Interdependence and War: A Theory of Trade Expectations. International Security, 20, 5-41. https://doi.org/10.1162/isec.20.4.5

Dunne, T. (2008). Liberalism. In J. Baylis, S. Smith, \& P. Owens (Eds.), The Globalization of World Politics (4th ed., pp. 108-123). Oxford University Press.

Gartzke, E., Li, Q., \& Boehmer, C. (2001). Investing in the Peace: Economic Interdependence and International Conflict. International Organization, 55, 391-438.

https://doi.org/10.1162/00208180151140612 
Gelpi, C., \& Grieco, J. (2008). Democracy Interdependence and the Sources of the Liberal Peace. Journal of Peace Research, 45, 17-36. https://doi.org/10.1177/0022343307084921

Gilpin, R. (1981). War and Change in World Politics. Cambridge University Press. https://doi.org/10.1017/CBO9780511664267

Goldsmith, B. (2013). International Trade and the Onset and Escalation of Interstate Conflict: More to Fight about, or More Reasons Not to Fight? Defence and Peace Economics, 24, 555-578. https://doi.org/10.1080/10242694.2013.763637

Gowa, J., \& Mansfield, E. D. (1993). Power Politics and International Trade. American Political Science Review, 87, 408-420. https://doi.org/10.2307/2939050

Grieco, J. (1988). Anarchy and the Limits of Cooperation: A Realist Critique of the Newest Liberal Institution. International Organization, 42, 485-507. https://doi.org/10.1017/S0020818300027715

Hegre, H. (2004). Development and the Liberal Peace: What Does It Take to Be a Trading State? Journal of Peace Research, 37, 5-30. https://doi.org/10.1177/0022343300037001001

Herge, H., Oneal, J., \& Russett, B. (2010). Trade Does Promote Peace: New Simultaneous Estimates of the Reciprocal Effects of Trade and Conflict. Journal of Peace Research, 47, 763-774. https://doi.org/10.1177/0022343310385995

Hirschman, A. (1945). National Power and the Structure of Foreign Trade. University of California Press.

Kapstein, E. (2003). Two Dismal Sciences Are Better than One-Economics and the Study of National Security. International Security, 27, 158-187. https://doi.org/10.1162/01622880260553660

Keohane, R., \& Nye, J. (1977). Power and Interdependence: World Politics in Transition. Little, Brown.

Keohane, R., \& Nye, J. (2001). Power and Interdependence (3rd ed.). Longman.

Keohane, R., \& Nye, J. (2013). Transnational Relations and World Politics. Harvard University Press. https://doi.org/10.4159/harvard.9780674593152

Krasner, S. (1979) Defending the National Interest: Raw Materials Investments and US Foreign Policy. Princeton University Press. https://doi.org/10.1515/9780691219516

Li, Q., \& Reuveny, R. (2011). Does Trade Prevent or Promote Interstate Conflict Initiation? Journal of Peace Research, 48, 437-453. https://doi.org/10.1177/0022343311406306

Li, Q., \& Sacko, D. (2002). The (Ir)Relevance of Militarized Interstate Disputes for International Trade. International Studies Quarterly, 46, 11-43. https://doi.org/10.1111/1468-2478.00221

Long, A. (2008). Bilateral Trade in the Shadow of Armed Conflict. International Studies Quarterly, 52, 81-101. https://doi.org/10.1111/j.1468-2478.2007.00492.x

Long, A., \& Leeds, B. (2006). Trading for Security: Military Alliances and Economic Agreements. Journal of Peace Research, 43, 433-451. https://doi.org/10.1177/0022343306065884

Maoz, Z. (2009). The Effects of Strategic and Economic Interdependence on International Conflict across Levels of Analysis. American Journal of Political Science, 53, 223-240. https://doi.org/10.1111/j.1540-5907.2008.00367.x

Martin, P., Mayer, T., \& Thoenig, M. (2008). Make Trade Not War? The Review of Economic Studies, 75, 865-900. https://doi.org/10.1111/j.1467-937X.2008.00492.x

Mastanduno, M. (1998). Economics and Security in Statecraft and Scholarship. Interna- 
tional Organization, 52, 825-854.

Morrow, J. (1999). How Could Trade Affect Conflict? Journal of Peace Research, 36, 481-489. https://doi.org/10.1177/0022343399036004006

OECD (2017). Trade in Value by Partner Countries. https://stats.oecd.org/Index.aspx?DataSetCode=PARTNER

Oneal, J., \& Russet, B. (1999). Assessing the Liberal Peace with Alternative Specifications: Trade Still Reduces Conflict. Journal of Peace Research, 36, 423-442. https://doi.org/10.1177/0022343399036004003

Poufinas, T., \& Pistikou, V. (2017). The Myth of the Positive Impact of Asymetric Economic Interdependence on National Security. The Case of the Sino-Japanese Conflict. KnE Social Sciences, 142-159.

Poufinas, T., \& Pistikou, V. (2018). A Financial Analysis Approach on the Promotion of Peace through Economic Interdependence. Theoretical Economics Letters, 8, 3611-3636. https://doi.org/10.4236/tel.2018.815222

Powers, K. (2004). Regional Trade Agreement as Military Alliances, International Interactions: Empirical and Theoretical Research. International Relations, 30, 373-395. https://doi.org/10.1080/03050620490884065

Seitz, M., Tarasov, A., \& Zakharenko, R. (2015). Trade Costs, Conflicts, and Defense Spending. Journal of International Economics, 95, 305-318.

https://doi.org/10.1016/j.jinteco.2014.11.013

The World Bank (2017). Exports of Goods and Services \& Imports of Goods and Services \& Military Expenditure. https://data.worldbank.org/indicator/

UN Comtrade (2018). International Trade Statistics Database. https://comtrade.un.org/

UNCTAD (2018). Trade Structure by Partner. https://stats.unctad.org/handbook/MerchandiseTrade/ByPartner.html

Wooldridge, J. M. (2016). Introductory Econometrics. A Modern Approach (6th ed.). Cengage Learning. 